\title{
Physico-chemical parameters and culturable yeast diversity in surface water: a consequence of pollution
}

\author{
Mzimkhulu Monapathi ${ }^{1,2}$, Carlos Bezuidenhout ${ }^{1}$ and Owen Rhode ${ }^{3}$ \\ 'Unit for Environmental Sciences and Management, North-West University, Potchefstroom, South Africa \\ 2Department of Chemistry, Faculty of Applied and Computer Science, Vaal University of Technology, Vanderbijlpark, South Africa \\ ${ }^{3}$ Agricultural Research Council-Grain Crops, Potchefstroom, South Africa
}

Rivers in the North West Province (NWP) of South Africa are polluted by various anthropogenic activities that are associated with agricultural, domestic, industrial, and mining activities. Pollutants and effluent resulting from these activities impact the physico-chemical and biological characteristics of river water. More particularly, domestic and agricultural pollution has been associated with the occurrence of pathogenic yeast species in water. The aim of this study was to determine physico-chemical parameters, yeast levels, and the antifungal susceptibility of pathogenic yeasts in river water. Physico-chemical parameters and yeast levels were determined using standard procedures. Yeasts were identified by biochemical tests and 265 rRNA gene sequencing. Disc diffusion antifungal susceptibility tests were conducted on identified potential pathogenic yeasts. Physico-chemical parameters were within target water quality ranges (TWQR) for livestock farming but were mostly out of range for irrigation. Yeast levels (incubation at $37^{\circ} \mathrm{C}$ ) ranged from 363 to $1778 \mathrm{CFU} / \mathrm{L}$. There were significant differences $(p<0.05)$ in the physico-chemical parameters and yeast levels between some seasons and among the river systems under study. A positive association was observed between temperature, COD and yeast levels in all the river systems. Ascomycetes, which were the most prevalent isolates, were identified as Candida spp. (35\%), Pichia spp. (13\%), Cyberlinera spp. (12\%), Meyerozyma spp. (11\%), Clavispora spp. (10\%), Saccharomyces spp. (6\%), Kluyveromyces spp. (5\%), Yamadazyma spp. (4\%), Trichosporon spp. (3\%), and Wickerhamomyces spp. (1\%). Antifungal resistance of the potential pathogenic yeasts was as follows: flucytosine and miconazole $(100 \%)>$ fluconazole $(78.5 \%)>$ econazole, and miconazole and ketoconazole $(49.6 \%)>$ nystatin $(15.2 \%)$. The river water systems explored in the study are used for agricultural, domestic and recreational purposes. Direct contact with the water, especially by immune-compromised people, may pose a health threat and should be further investigated.

\section{CORRESPONDENCE}

Mzimkhulu Monapathi

\section{EMAIL}

monapathimz@gmail.com

\section{DATES}

Received: 25 February 2020

Accepted: 2 October 2020

\section{KEYWORDS}

water quality surface water physico-chemical parameters pathogenic yeasts antifungal susceptibility

\section{COPYRIGHT}

(c) The Author(s)

Published under a Creative

Commons Attribution 4.0

International Licence

(CC BY 4.0)

\section{INTRODUCTION}

Organic and inorganic pollutants, heavy metals and biological materials from industries, mines, wastewater treatment plants (WWTPs) and agricultural settings are known to be indiscriminately discharged into river systems (Gupta et al., 2017). These surface and subsurface water resources are used for drinking water supply, domestic use, agricultural irrigation and aquatic life. Pollutants affect the physico-chemical parameters and microbial density present in water systems (Traoré et al., 2016) and thus water use prospects are affected. The Sustainable Development Goals (SDG) adopted by all United Nations member states in 2015 stipulate that all people should have access to clean water, sanitation, good health, and wellbeing by 2030 (UNDP, 2015). However, water pollution derived from human activities threatens the achievement of the SDG targets.

Current microbial studies use standard faecal indicator bacteria such as Escherichia coli and intestinal enterococci to determine water pollution levels (Kirschner et al., 2019). However, some studies have also reported high yeast levels and the presence of certain types of yeasts as an indication of contaminated water environments (Van Wyk et al., 2012; Monapathi et al., 2017). Some studies have also deemed yeasts as a complement to faecal indicator bacteria counts when water quality is monitored (Medeiros et al., 2008; Brandão et al., 2010). A rapid response of yeasts to organic contamination makes some yeasts important indicators of nutrient enrichment because these convert easily accessible carbon sources into energy for reproduction (Brandão et al., 2010).

Pathogenic yeast species have been isolated from freshwater environments (Monapathi et al., 2020). They can cause various diseases - from superficial mucosal infections to life-threatening systemic disorders, especially in immunocompromised people (Ravikumar et al., 2015). These patients are generally associated with cancer, organ transplants, and HIV (Shiels et al., 2017). The situation is exacerbated as pathogenic yeast species have developed resistance to several of the clinically used antifungal agents (Ksiezopolska and Gabaldón, 2018).

Sub-therapeutic levels of antifungal agents are constantly leaked into the environment by means of wastewater treatment plant (WWTP) discharges and agricultural runoff (Tran et al., 2017). The release of such effluent into aquatic ecosystems escalates antifungal resistance through continuous exposure of pathogenic yeasts. Antifungal resistance has been observed among environmental isolates (Brilhante et al., 2016; Milanezi et al., 2019; Monapathi et al., 2017, 2018). According to a report by the UN ad hoc Interagency Coordinating Group on Antimicrobial Resistance, 


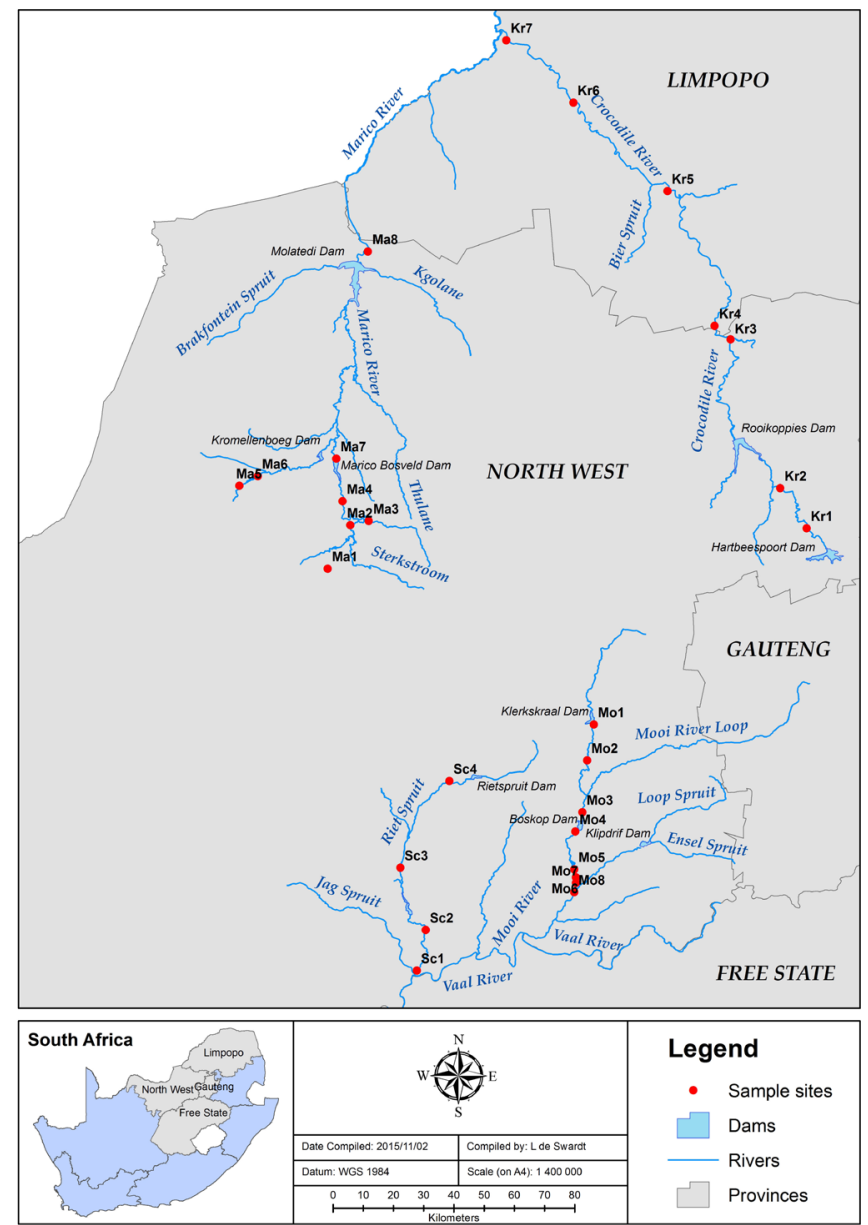

Figure 1. Map showing the selected river systems in the North West Province of South Africa (Mo = Mooi River; Ma = Marico River; $\mathrm{Sc}=$ Schoonspriut River; $\mathrm{Kr}=$ Crocodile River)

drug-resistant diseases could cause up to 10 million deaths each year by 2050. Furthermore, by 2030, antimicrobial resistance could force up to 24 million people into extreme poverty (WHO, 2016). Antifungal drug resistance by pathogenic yeasts is a pressing public health crisis. The present study thus aimed to determine physico-chemical parameters and yeast levels as well as the antifungal susceptibility of pathogenic yeasts in four selected river systems in the North West Province (NWP) of South Africa.

\section{METHODS}

\section{Study area}

Water samples were collected from 4 river systems: the Mooi River, the Schoonspruit River, the Crocodile (West) River, and the Marico River, South Africa (Fig. 1). A Garmin Nüvi 1310 (Garmin, US) global positioning system (GPS waypoints) was used to locate the water sampling sites. Water quality of these river systems is affected by surrounding informal settlements, urbanization, agricultural runoff, and industrial and mining activities (DWAF, 2004, 2007, 2009; Winde, 2010; Barnard et al., 2013; Venter et al., 2013).

\section{Sampling}

Sampling was conducted in 2015 and 2016 during the wetwarm (August to March) and dry-cold seasons (May to July) in the NWP. An aquatic microbiology research group at the North West University assisted with sampling. Water samples (1 L were collected using sterile Schott bottles. The direct sampling technique was used close to the riverbank. Dip sampling was done using a rope where direct access to the surface water systems was limited (Van Wyk et al., 2012).

\section{Physico-chemical parameter analyses}

Physico-chemical parameter analyses were done in triplicate. Temperature, $\mathrm{pH}$, dissolved oxygen (DO) and total dissolved solids (TDS) were determined in situ using a 350 multi parameter probe (Merck, Germany). Water samples were transported on ice to the laboratory and analysed within $8 \mathrm{~h}$ for nitrates (Method 10206), phosphates (Method 8048) and chemical oxygen demand (COD) (Method 8000) using the Hach Lange DR 2800 system and reagents (Hach Company, 2007). Raw data for physico-chemical parameters have been reported by Bezuidenhout et al. (2018).

\section{Yeast isolation and enumeration}

Membrane filtration was done to determine the presence of yeasts in the water samples as described by Van Wyk et al. (2012). Water samples $(100 \mathrm{~mL})$ were filtered in triplicate through $0.45 \mu \mathrm{m}$ HA membrane filters (Whatman). Membranes were placed on yeast-malt-extract (YM) plates, supplemented with $100 \mathrm{ppm}$ chloramphenicol, and incubated at room temperature (incubation in the laboratory under uncontrolled conditions) and at $37^{\circ} \mathrm{C}$ for $24 \mathrm{~h}$. Colony counts were done on individual plates. Representatives of morphotypes that grew at $37^{\circ} \mathrm{C}$ with respect to cellular shapes, colonial elevation, colonial surface, and colonial pigmentation were selected and purified by sub-culturing on YM plates (Wickerham, 1951) and subjected to further analysis.

\section{Biochemical characterisation}

\section{Diazonium Blue B (DBB) test}

Yeast cultures were grown on YM agar plates and incubated at $37^{\circ} \mathrm{C}$ for $14-21$ days (Kurtzman and Fell, 1998). Petri dishes were 
flooded with ice-cold DBB reagent (0.1MTris-HCl; Diazonium Blue B Salt $1 \mathrm{mg} / \mathrm{mL}$ ) (Prillinger et al., 1999). A dark red to violet red colour occurring within $2 \mathrm{~min}$ at room temperature indicated a positive reaction for basidiomycetes (Kurtzman and Fell, 1998).

\section{Molecular identification}

\section{DNA extraction}

Two millilitres overnight YM broth cultures of the yeast isolates were prepared and centrifuged to obtain a pellet of the cells. This was followed by genomic DNA extraction according to the modified method of Hoffman and Winston (1987).

\section{Amplification and sequence validation}

The 26S rRNA gene fragments of the extracted DNA were amplified using the polymerase chain reaction (PCR) procedure as described by Monapathi et al. (2017). Forward primers, NL1 (5-GCATATCAATAAGCGGAGGAAAAG-3) and reverse primers, NL4 (5-GGTCCGTGTTTCAAGACGG-3) (O’Donnell, 1993) were used. PCR products were sequenced using the BigDye Terminator version 3.1 Cycle Sequencing kit (Applied Biosystems, $\mathrm{UK}$ ) as prescribed by the manufacturer.

Clean-up of the sequencing reaction was achieved using the $\mathrm{NaOAc/}$ EDTA/ethanol method (Applied Biosystems, UK) and sequenced using an ABI 3130 Genetic Analyser (Applied Biosystems, Hitachi) (Jordaan and Bezuidenhout, 2013). BLAST (Altschul et al., 1997) searches (http://www.ncbi.nlm.nih.gov/BLAST) were used to determine the identity of the amplified sequences. Sequence reads were submitted to a NCBI GenBank database.

\section{Antifungal susceptibility tests}

Antifungal susceptibility testing using the Kirby-Bauer disc diffusion method (Bauer et al., 1966) was done using YM agar. Diameters of zones of inhibition (in $\mathrm{mm}$ ) of yeast species against commonly used antifungal agents: fluconazole (FCN; $25 \mu \mathrm{g}$ ), econazole (ECN: $1 \mu \mathrm{g})$, ketoconazole (KCA: $15 \mu \mathrm{g}$ ), miconazole (MCL: $1 \mu \mathrm{g}$ ), metronidazole (MZ: $5 \mu \mathrm{g}$ ), flucytosine (FY: $1 \mu \mathrm{g}$ ), and nystatin (NY: 100) were measured after a 24 -h incubation period at $37^{\circ} \mathrm{C}$. These were compared to the susceptibility breakpoints for fluconazole and Candida spp. (Pfaller et al., 2006). Zone breakpoints and interpretative categories for antifungal agents were classified as resistant $(\geq 19 \mathrm{~mm})$, susceptible-dose dependent (15 to $18 \mathrm{~mm}$ ), or susceptible $(\leq 14)$.

\section{Data and statistical analyses}

Microsoft Excel (2016) was used to analyse data. Descriptive and one-way ANOVA followed by Tukey's HSD (Honestly Significant Difference) Test for unequal sample sizes were used for post-hoc comparisons of physico-chemical and microbiological parameters where $p<0.05$ was deemed significant. Significant differences were denoted by different alphabetical letters ( $a, b, c, d$, e, etc.) between variables. Redundancy analysis (RDA) was used to test for association between physico-chemical parameters and yeast levels. Data output was provided as correlation biplots. The correlation significance level was set at $p<0.05$.

\section{RESULTS AND DISCUSSION}

\section{Physico-chemical parameters and yeast levels}

The mean values of the physico-chemical parameters were compared to water quality standards defined in Total Water Quality Ranges (TWQR) for agricultural applications (irrigation and livestock farming) (DWAF, 1996a, 1996b). Temperatures for the wet-warm seasons were significantly higher $(p<0.05)$ than for the dry-cold seasons (Fig. 2 I). During the wet rainy season, organic pollutants from domestic wastewater, effluent from wastewater treatment plants, and agricultural runoff are leached into environmental water which results in increased water temperature (Susilowati et al., 2018). The high temperatures observed in the present study resulted from discharges and run-off from agricultural settings, informal settlements, and urbanization activities in the vicinity of the river systems.

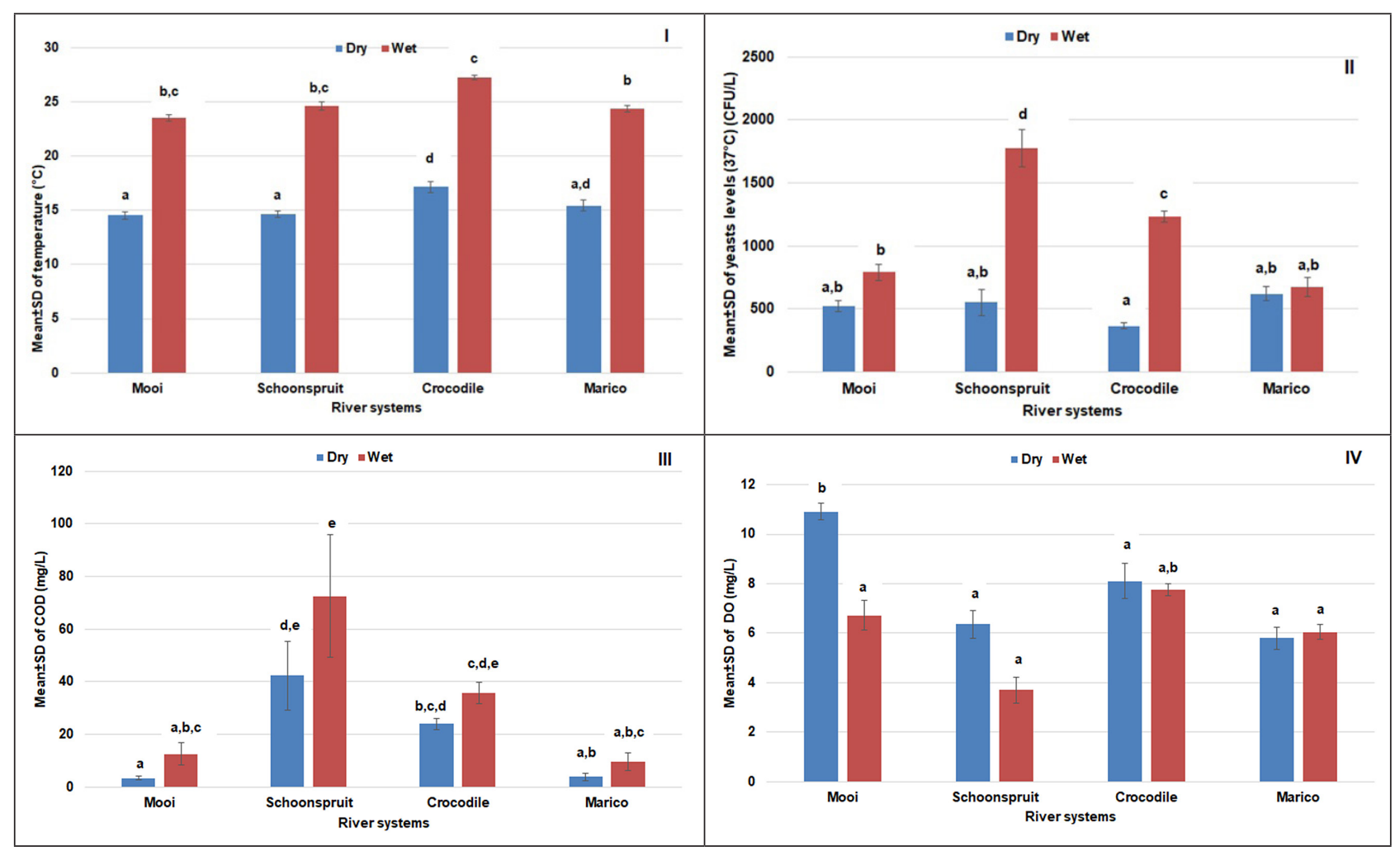

Figure 2. Mean \pm SD values for physico-chemical and microbiological parameters in selected surface water resources in the NWP; (I) temperature ( $\left.{ }^{\circ} \mathrm{C}\right)$, (II) yeast levels at $37^{\circ} \mathrm{C}$ (CFU/L), (III) chemical oxygen demand (COD) (mg/L), (IV) dissolved oxygen (DO) (mg/L) 


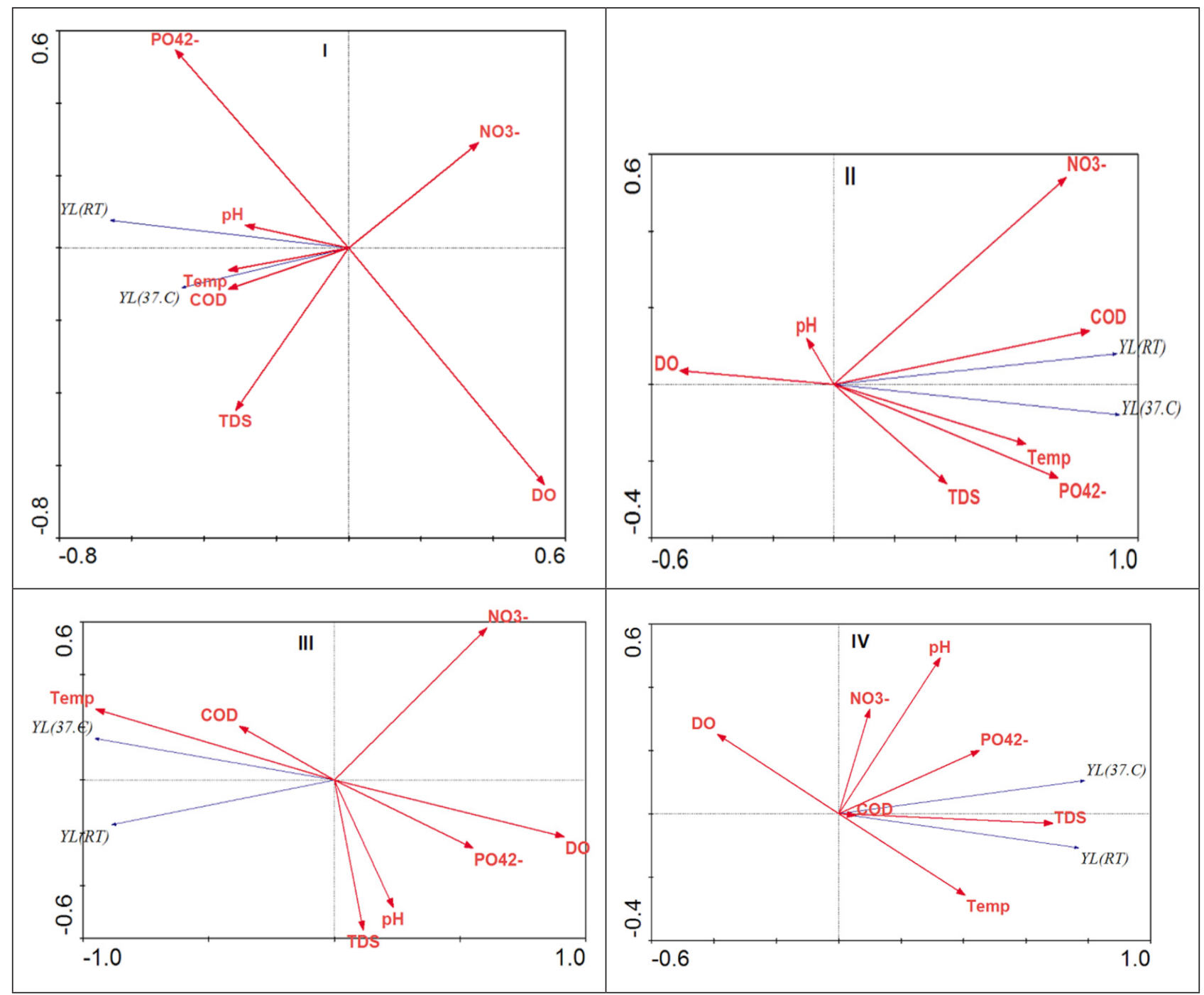

Figure 3. Redundancy analysis (RDA) ordination biplots illustrating correlation between environmental variables and yeast levels (YL) in the river systems under study: (I) Mooi River (II) Schoonspruit River (III) Crocodile (West) River and (IV) Marico River. Temp = temperature; TDS = total dissolved solids; $\mathrm{COD}=$ chemical oxygen demand: $\mathrm{DO}=$ dissolved oxygen; $\mathrm{NO}-{ }_{-}^{-}$nitrates $\left(\mathrm{NO}_{3}{ }^{-}\right) ; \mathrm{PO}^{-} 2^{-}=\mathrm{phosphates}\left(\mathrm{PO}_{4}{ }^{2-}\right)$

Yeasts require carbon sources for energy and growth (Tomova et al., 2019); thus a polluted organic state of the river systems will favour the growth of yeasts. Yeast levels enumerated at $37^{\circ} \mathrm{C}$ were between 363 and 1778 CFU/L (Fig. 2 II). High yeast levels were recorded for all sampling sites during the wet-warm seasons. At room temperature (RT), the yeast levels followed a similar trend and a positive association is depicted in Fig. 3 (I, II, III, IV). At room temperature, the yeast levels were substantially higher (data not shown). An increase in temperature results in increased concentration of dissolved substances and a decreased concentration of dissolved oxygen (Rajwa-Kuligiewicz et al., 2015; Susilowati et al., 2018). Maximum COD concentrations for wet-warm and dry-cold seasons were $72.5 \mathrm{mg} / \mathrm{L}$ and $42.3 \mathrm{mg} / \mathrm{L}$, respectively (Fig. $2 \mathrm{III}$ ).

From RDA, a positive association was observed between yeast levels, temperature, and $\mathrm{COD}$ in all the river systems (Fig. 3 I, II, III, IV). A negative correlation was observed with DO. This conformed to lower DO levels $(\leq 7.8 \mathrm{mg} / \mathrm{L})$ during the wetwarm season (Fig. 2 IV).

The $\mathrm{pH}$ values for the wet-warm and dry-cold seasons varied between 7 and 8 but were within the acceptable TWQR for irrigational use (6.5-8.4). The $\mathrm{pH}$ values were slightly alkaline. Organic matter from anthropogenic pollutants decreases the $\mathrm{pH}$ in water (Schneider and Le Campion-Alsumald, 1999). Maximum TDS values recorded were $720 \mathrm{mg} / \mathrm{L}$ and $711 \mathrm{mg} / \mathrm{L}$ for the wetwarm and dry-cold seasons (Fig. 2 III). Significantly higher
TDS values were observed for the Schoonspruit River samples compared to the other rivers. RDA showed a positive association between TDS, yeast levels, temperature, and COD for the Marico and Schoonspruit River samples (Fig. 3 II, IV). TDS values were within TWQR for livestock farming $(<1000 \mathrm{mg} / \mathrm{L})$ but above the recommended values for irrigation use $(>40 \mathrm{mg} / \mathrm{L})$. The high TDS values that were found in the NWP rivers by the current and by previous studies (Van Wyk et al., 2012; Monapathi et al., 2017) could have occurred as a result of dolomitic springs which are water sources for some of the river systems (Van Der Walt, 2002).

Nitrate levels for the wet-warm and the dry-cold seasons were $\leq 1.8 \mathrm{mg} / \mathrm{L}$ and $\leq 1.51 \mathrm{mg} / \mathrm{L}$, respectively, while the phosphate concentrations for the wet-warm and dry-cold seasons were recorded as $\leq 5.4 \mathrm{mg} / \mathrm{L}$ and $\leq 1.8$, respectively. No significant seasonal differences were observed per river system and among the river systems for the latter nutrient. Moreover, no clear association could be established between the nutrients and yeast levels, except for phosphates in the Marico and Schoonspruit Rivers.

The river systems explored in the present study are used for irrigation purposes. However, the mean nitrate levels were above the permissible TWQR levels $(<0.5 \mathrm{mg} / \mathrm{L})$ for irrigation use. Dryland farming practices in the NWP use fertilisers and animal manure (Jordaan and Bezuidenhout, 2016). The nutrients observed in the river systems could have resulted from surrounding agricultural activities. 


\section{Biochemical and molecular identification of yeasts}

DBB staining classified yeasts as ascomycetous yeasts. In the four rivers, a total of 256 isolates were obtained and identified (Mooi River $=99$; Schoonspruit River $=84$; Marico River $=43$; Crocodile (West) River $=30$. BLAST searches determined the identity of the amplified 26S rRNA gene sequences. The following genera were identified: predominant Candida spp. (35\%), Pichia spp. (13\%), Cyberlinera spp. (12\%), Meyerozyma spp. (11\%), Clavispora spp. (10\%), Saccharomyces spp. (6\%), Kluyveromyces spp. (5\%), Trichosporon spp. (4\%), Yamadazyma spp. (3\%), and Wickerhamomyces spp. (1\%).

Figures 4 I and II show a neighbour-joining tree demonstrating a phylogenetic analysis between yeast species. Medium to high bootstrap confidence of 66 to $100 \%$ supported the relationship between the environmental isolates (bolded) and the representative 26S rRNA gene sequences obtained from GenBank database. A phylogenetic tree constructed from sequences of Candida species (Fig. 4 I) showed the formation of distinct clusters for each species. Each cluster indicated high sequence similarity between the groups (Ragonnet-Cronin et al., 2013). Clustering of similar species was also observed in nonCandida species (Fig. 4 II). Clusters $\mathrm{H}$ and $\mathrm{K}$ were outgroups for Candida and non-Candida groups, respectively. Pathogenic species did not form a monophyletic group and were scattered all over the trees. This indicated that pathogenicity amongst these species evolved independently on multiple occasions (Diezmann et al., 2004).

(I)

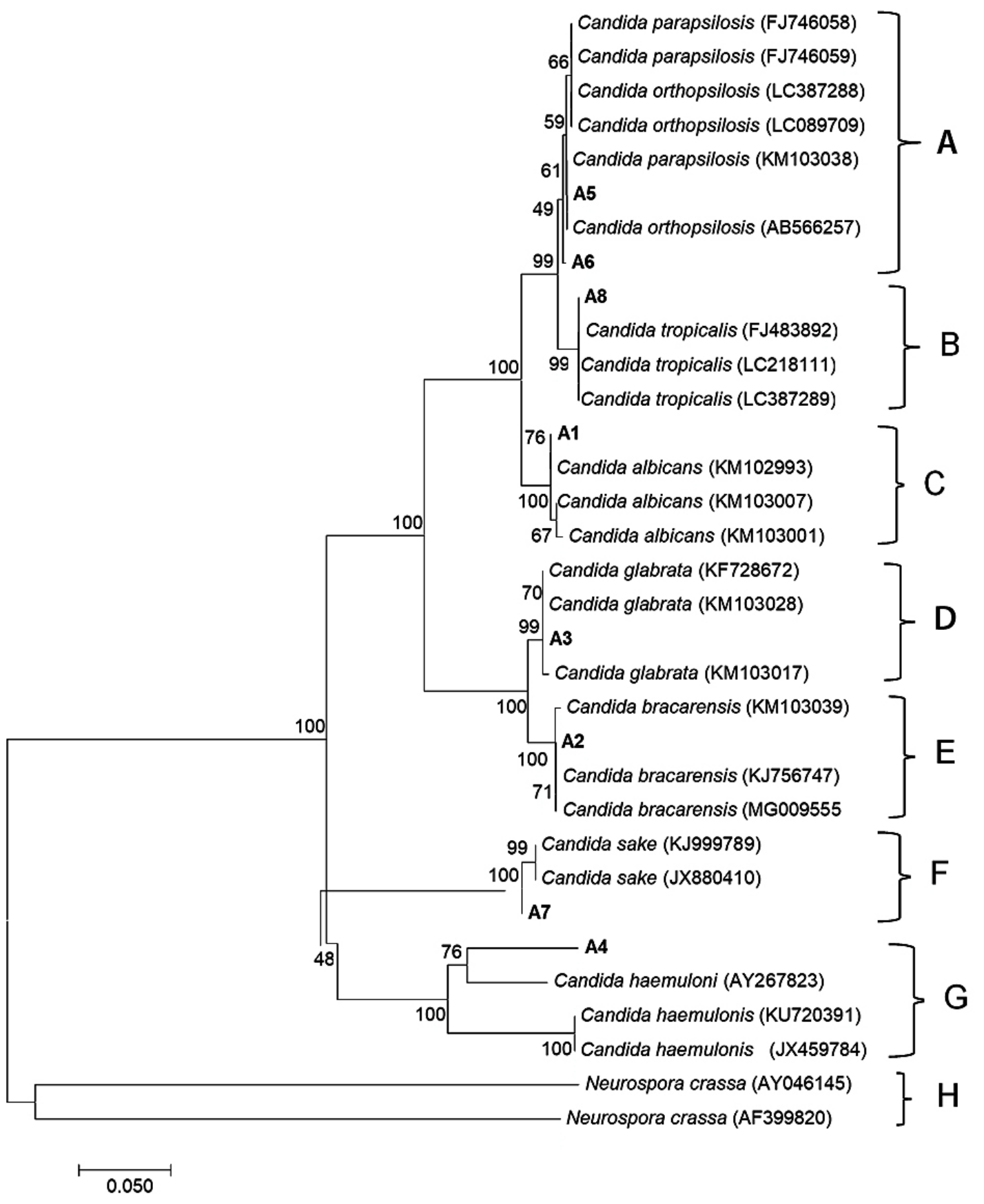

Figure 4. A neighbour-joining tree showing the phylogenetic relationship between environmental Candida species (I) and non-Candida species (II) (bold) and representative species from GenBank database. A bootstrap test (1 000 replicates) was conducted and the cluster percentages of trees supporting the cluster are provided. 


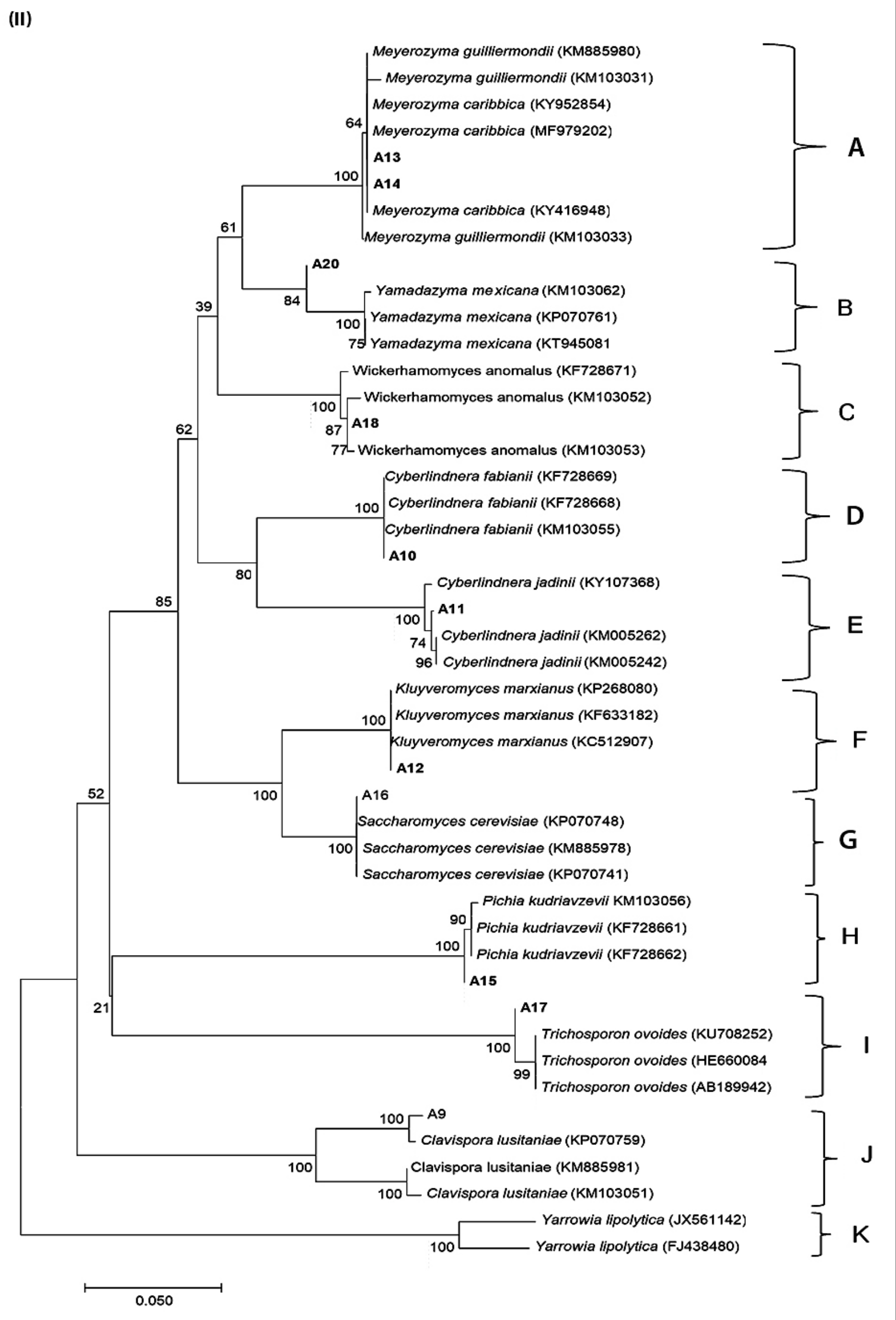

Figure 4 Continued. A neighbour-joining tree showing the phylogenetic relationship between environmental Candida species (I) and nonCandida species (II) (bold) and representative species from GenBank database. A bootstrap test (1 000 replicates) was conducted and the cluster percentages of trees supporting the cluster are provided. 
Table 1. Isolated yeast species' resistance (\%) to commonly used antifungal agents. ( $F C N=$ fluconazole; $E C N=e z o n a z o l e ; ~ K C A=k e t o c o n a z o l e$ $\mathrm{MCL}=$ miconazole $\mathrm{MZ}=$ metronidazole; $\mathrm{FY}=$ fluctyosine; $\mathrm{NY}=$ nystatin)

\begin{tabular}{|c|c|c|c|c|c|c|c|}
\hline \multirow[t]{2}{*}{ Yeast species } & \multicolumn{7}{|c|}{ Antifungal agents (\% resistance) } \\
\hline & FCN & ECN & KCA & $\mathrm{MCL}$ & MZ & FY & NY \\
\hline $\begin{array}{l}\text { Candida albicans, C. glabrata, C. haemulonis, C. orthopsilosis, } \\
\text { C. sake, C. tropicalis, Clavispora lusitaniae, Trichosporon ovoides }\end{array}$ & 100.0 & 100.0 & 100.0 & 100.0 & 100.0 & 100.0 & 0.0 \\
\hline $\begin{array}{l}\text { Candida bracarensis, Pichia kudriavzevii, Saccharomyces } \\
\text { cerevisiae }\end{array}$ & 100.0 & 0.0 & 0.0 & 0.0 & 100.0 & 100.0 & 0.0 \\
\hline Candida parapsilosis & 0.0 & 0.0 & 0.0 & 0.0 & 100.0 & 100.0 & 100.0 \\
\hline $\begin{array}{l}\text { Cyberlinera fabianii, Cyberlindnera jadinii, Kluyveromyces } \\
\text { marxianus, Wickerhamomyces anomalus, Yamadazyma } \\
\text { mexicana }\end{array}$ & 0.0 & 0.0 & 0.0 & 0.0 & 100.0 & 100.0 & 0.0 \\
\hline Meyerozyma caribbica, M. guilliermondii & 100.0 & 0.0 & 0.0 & 0.0 & 100.0 & 100.0 & 100.0 \\
\hline
\end{tabular}

Table 2. Number of yeast isolates $(n(\%))$ resistant to various commonly used antifungals

\begin{tabular}{|c|c|c|c|c|c|c|c|}
\hline \multirow[t]{2}{*}{ Sampling site } & \multicolumn{7}{|c|}{ Antifungal agents } \\
\hline & FCN & ECN & KCA & MCL & $M Z$ & FY & NY \\
\hline Mooi River $(n=99)$ & $78(78.8)$ & $58(58.6)$ & $58(58.6)$ & $58(58.6)$ & $99(100)$ & $99(100)$ & $6(6.1)$ \\
\hline Schoonspruit River $(n=84)$ & $59(70.2)$ & $35(41.7)$ & $35(41.7)$ & $35(41.7)$ & $84(100)$ & $84(100)$ & 11(13.1) \\
\hline Marico River $(n=43)$ & $38(88)$ & $21(48.8)$ & $21(48.8)$ & $21(48.8)$ & $43(100)$ & 43(100) & $9(20.9)$ \\
\hline Crocodile River $(n=30)$ & $26(86.7)$ & $13(43.3)$ & 13(43.3) & $13(43.3)$ & $30(100)$ & $30(100)$ & $8(12.5)$ \\
\hline Total $(n=256)$ & $201(78.5)$ & $127(49.6)$ & $127(49.6)$ & $127(49.6)$ & $256(100)$ & $256(100)$ & $39(15.2)$ \\
\hline
\end{tabular}

\section{Pathogenic yeasts}

Yeast species that grow at $37^{\circ} \mathrm{C}$ are opportunistic pathogens (Maciel et al., 2019). The predominantly isolated species in the current study, Candida spp., are widely recognized as major causes of morbidity and mortality in the healthcare environment. Some pathogenic Candida species are C. albicans, C. glabrata, C. tropicalis, C. parapsilosis, and C. krusei (Zupančič et al., 2018, Friedman and Schwartz, 2019). Opportunistic non-Candida yeasts spp. isolated in the present study were Clavispora lusitaniae, Cyberlinera fabianii, Meyerozyma caribbica, M. guilliermondii, S. cerevisiae, T. ovoides, and $W$. anomalus. These organisms have been implicated in causing cutaneous and/or systemic bloodstream infections such as vaginitis in healthy patients, endophthalmitis, candidemia, trichosporonosis, and catheter-related, neonatal and ocular infections in immunecompromised people (Gabaldón et al., 2016; Maciel et al., 2019; Consortium Opathy and Gabaldón, 2019).

\section{Antifungal susceptibility pattern}

Yeast species showed antifungal resistance to various commonly used antifungals. Table 1 illustrates that pathogenic yeasts Candida albicans, C. glabrata, C. haemulonis, C. orthopsilosis, C. sake, C. tropicalis, Clavispora lusitaniae and Trichosporon ovoides showed $100 \%$ resistance to azoles. Opportunistic non-Candida yeasts were also resistant to azoles. In the entire study, all the isolated yeast species were resistant to metronidazole and flucytosine (Table 2), followed by fluconazole (78.5\%), econazole, miconazole and ketoconazole (49.6\%) and nystatin (15.2\%). Predominant resistance to fluconazole was observed in all the river systems. The high resistance to azoles that was observed is worrisome. Due to their broad spectrum of activity and safety profiles, azoles are the most commonly used antifungal drugs (Li et al., 2014).

Several studies have reported on environmental yeast resistance to antifungal drugs. A study conducted by Brilhante et al. (2016) at Catú Lake, Ceará, in Brazil, detected 13 azole-resistant Candida isolates. Antifungal resistance was also observed to amphotericin B, itraconazole, and fluconazole. Milanezi et al. (2019) conducted a study in the Dilúvio Stream in Porto Alegre, Rio Grande do Sul, Brazil. The isolated Candida spp., Debaryomyces spp. and Rhodotorula spp. were resistant to itraconazole (57.9\%), fluconazole (44.2\%), voriconazole (24.2\%), amphotericin B 16 $(16.8 \%)$, and ketoconazole (5.3\%).

Monapathi et al. (2017) analysed antifungal susceptibility in the Mooi River and the Harts River in South Africa. All tested yeast isolates (100\%) were resistant to miconazole and flucytosine. These were followed by fluconazole ( 88.5 and $92.5 \%$ ) in the Mooi and Harts Rivers, respectively). In the Mooi River, $62.8 \%$ of the isolates were resistant to econazole and miconazole and $64.1 \%$ were resistant to ketoconazole. In the Harts River, $12.5 \%$ of the isolates were resistant to the three azole antifungal drugs. These results are similar to the findings of the present study. Azole resistance was common amongst the isolates from the four river systems and thus aquatic environments hosting these pathogenic antifungal resistant yeasts might pose a public health threat. With the high HIV infection rate in South Africa (7.2 million) (UNAIDS, 2018), resistance of pathogenic yeasts to antifungal agents places people at risk who use surface water, such as the communities in the vicinity and visitors to the river areas for recreation or other purposes.

\section{CONCLUSIONS}

Physico-chemical parameters and yeast levels were determined in four rivers system in the NWP. The river systems are used for agricultural, domestic, industrial and mining purposes. Physico-chemical parameters were within TWQR for livestock farming but were out of range for irrigation. Higher yeast levels observed during the wet-warm seasons correlated with elevated temperatures and COD levels. Further studies are needed to increase the datasets for yeasts used in conjunction with physicochemical parameters. Isolated yeasts were ascomycetes and were dominated by Candida spp., many of which are pathogens/ opportunistic pathogens. Of concern is that these Candida spp. that were prevalent are resistant to antifungal agents commonly used in human and animal therapeutic settings. The observed resistance to azole, especially fluconazole, is also a concern. 
There is high HIV prevalence in South Africa and fluconazole is part of antiretroviral therapy to prophylactically manage potential Candida spp. infections. The results demonstrate the attractiveness of using yeasts as a microbiological indicator of organic pollution of aquatic ecosystems. The results also demonstrate that veterinary and agricultural use of antifungal drugs should be regulated and minimised to prevent antifungal resistance of potential pathogenic yeasts in aquatic systems. Further studies on antifungal susceptibility and mechanisms should be conducted to find solutions for resistance and to validate the development of new antifungal drugs.

\section{REFERENCES}

ALTSCHUL SF, MADDEN TL, SCHAFFER AA, ZHANG J, ZHANG Z, MILLER W and LIPMAN DJ (1997) Gapped BLAST and PSI-BLAST: a new generation of protein database search programs. Nucleic Acids Res. 25 3389-3402. https://doi.org/10.1093/nar/25.17.3389

BARNARD S, VENTER A and VAN GINKEL C (2013) Overview of the influences of mining-related pollution on the water quality of the Mooi River system's reservoirs, using basic statistical analyses and self-organized mapping. Water SA. 39 (5) 655-662. https://doi. org/10.4314/wsa.v39i5.10

BAUER A W, KIRBY WMM, SHERRIS JC and TURCK M (1966) Antibiotic susceptibility testing by a standardized single disk method. Am. J. Clin. Path. 45 (4) 493-496. https://doi.org/10.1093/ajcp/45.4_ ts. 493

BEZUIDENHOUT CC, MIENIE C, DE KLERK T and MOLALE L (2018) Geospatial analysis of microbial community structure and antimicrobial resistance analysis in the management of natural streams and selected wetlands. WRC Report No. 2347/1/18, Water Research Commission, Pretoria.

BRANDAO LR, MEDEIROS AO, DUARTE MC, BARBOSA AC and ROSA CA (2010) Diversity and antifungal susceptibility of yeasts isolated by multiple-tube fermentation from three freshwater lakes in Brazil. J. Water Health. 8 (2) 279-289. https://doi.org/10.2166/ wh.2009.170

BRILHANTE RS, PAIVA MA, SAMPIAO CM, CASTELO-BRANCO DS, TEIXEIRA CE, DE ALENCAR LP, BANDEIRA TJPG, MONTEIRO AJ, CORDEIRO RA, PEREIRA-NETO WA and coauthors (2016) Azole resistance in Candida spp. isolated from Catu Lake, Ceara, Brazil: an efflux-pump-mediated mechanism. Braz. J. Microbiol. 47 33-38. https://doi.org/10.1016/j.bjm.2015.11.008

CONSORTIUM OPATHY and GABALDON T (2019) Recent trends in molecular diagnostics of yeast infections: from PCR to NGS. FEMS Microbiol. Rev. 43 (5) 517-547.

DIEZMANN S, COX CJ, SCHONIAN G, VILGAL RJ and MITCHELL TG (2004) Phylogeny and evolution of medical species of Candida and related taxa: a multigenic analysis. J. Clin. Microbiol. $425624-$ 5635. https://doi.org/10.1128/JCM.42.12.5624-5635.2004

DWAF (Department of Water Affairs and Forestry, South Africa) (1996a) South African Water Quality Guidelines; Agricultural Use; Irrigation. Volume 4, Field Guide ( $\left.1^{\text {st }} \mathrm{edn}\right)$. DWAF, Pretoria.

DWAF (Department of Water Affairs and Forestry, South Africa) (1996b) South African Water Quality Guidelines; Agricultural Use; Livestock Farming. Volume 5, Field Guide ( $\left.1^{\text {st }} \mathrm{edn}\right)$. DWAF, Pretoria.

DWAF (Department of Water Affairs and Forestry, South Africa) (2004) Middle Vaal water management area: internal strategic perspective. DWAF Report No WMA 10/000/00/0304. DWAF, Pretoria.

DWAF (Department of Water Affairs and Forestry, South Africa) (2007) Habitat integrity of selected rivers of the North West Province. Government Printer, Pretoria.

DWAF (Department of Water Affairs and Forestry, South Africa) (2009) Adopt-a-River Programme Phase II: Development of an implementation plan. Water resource quality situation assessment. Prepared by H. Hendriks and J.N. Rossouw for Department of Water Affairs. DWAF, Pretoria.

FRIEDMAN D and SCHWARTZ IS (2019) Emerging fungal infections: New patients, new patterns, and new pathogens. J. Fungi 5 (3) 67. https://doi.org/10.3390/jof5030067

GABALDON T, NARANJO ORTIZ MA and MARCET-HOUBEN M (2016) Evolutionary genomics of yeast pathogens in the Saccharomycotina. FEMS Yeast Res. 16 (6) fow064. https://doi.org/10.1093/ femsyr/fow064
GUPTA N, PANKAJ P and HUSSAIN J (2017) Effect of physicochemical and biological parameters on the quality of river water of Narmada, Madhya Pradesh, India. WaterSci. 31 11-23. https://doi.org/10.1016/j. wsj.2017.03.002

HACH COMPANY (2007) DR (2800) Spectrophotometer: Procedures Manual. ( $2^{\text {nd }}$ edn). Hach Company, Germany.

HOFFMAN CS and WINSTON E (1987) A ten-minute DNA preparation from yeast efficiently releases autonomous plasmids for transformation of Escherichia coli. Gene 57 267-272. https://doi.org/ 10.1016/0378-1119(87)90131-4

JORDAAN K and BEZUIDENHOUT CC (2013) Bacterial community structures in the Vaal River System, South Africa using PCR-DGGE and high-throughput sequencing. Water SA. 39 (3) 365-375. https:// doi.org/10.4314/wsa.v39i3.7

JORDAAN K and BEZUIDENHOUT CC (2016) Bacterial community composition of an urban river in the North West Province, South Africa, in relation to physico-chemical water quality. Environ. Sci. Pollut. Res. 23 5868-5880. https://doi.org/10.1007/s11356-015-5786-7

KIRSCHNER A, REISCHER GH, JAKWERTH S, SAVIO D, IXENMAIER S, TOTH E, SOMMER R, MACH RL, LINKE R, EILER A and co-authors (2017) Multiparametric monitoring of microbial faecal pollution reveals the dominance of human contamination along the whole Danube River. Water Res. 124 543-555. https://doi. org/10.1016/j.watres.2017.07.052

KSIEZOPOLSKA E and GABALDON T (2018) Evolutionary emergence of drug resistance in Candida opportunistic pathogens. Genes. 9 461. https://doi.org/10.3390/genes9090461

KURTZMAN CP and FELL JW (1998) The Yeasts: A Taxonomic Study $\left(4^{\text {th }}\right.$ edn $)$. Elsevier, Amsterdam.

LI LJ, DING H, WANG BJ, YU SC, ZOU Y, CHAI XY and WU QY (2014) Synthesis and evaluation of novel azoles as potent antifungal agents. Bioorganic Med. Chem. Lett. 24 192-194. https://doi.org/10.1016/j. bmcl.2013.11.037

MACIEL NO, JOHANN S, BRANDAO LR, KUCHARIKOVA S, MORAIS CG, OLIVEIRA AP, FREITAS GJC, BORELLI MB, PELLIZZARI MF, SANTOS AD and co-authors (2019) Occurrence, antifungal susceptibility, and virulence factors of opportunistic yeasts isolated from Brazilian beaches. Mem. Inst. Oswaldo Cruz. 114 e180566. https://doi.org/10.1590/0074-02760180566

MEDEIROS OA, KOHLER L, HAMDAN J, MISSAGIA B, BARBOSA F and ROSA C (2008) Diversity and antifungal susceptibility of yeasts from tropical fresh environments in southeastern Brazil. Water Res. 42 3921-3929. https://doi.org/10.1016/j.watres.2008.05.026

MILANEZI ACM, WITUSK JPD and VAN DER SAND ST (2019) Antifungal susceptibility of yeasts isolated from anthropogenic watershed. An. Acad. Bras. Ciên. 91 (1) e20170369. https://doi.org/ 10.1590/0001-3765201820170369

MONAPATHI ME, BEZUIDENHOUT CC and RHODE OHJ (2017) Water quality and antifungal susceptibility of opportunistic yeast pathogens from rivers. Water Sci. Technol. 6 (75) 1319-1331. https:// doi.org/10.2166/wst.2016.580

MONAPATHI ME, BEZUIDENHOUT CC and RHODE OHJ (2018) Efflux pumps genes of clinical origin are related to those from fluconazole resistant Candida albicans isolates from environmental water. Water Sci. Technol. 77 (3-4) 899-908. https://doi.org/10.2166/ wst.2017.607

MONAPATHI ME, BEZUIDENHOUT CC and RHODE OHJ (2020) Aquatic yeasts: diversity, characteristics and potential health implications. J. Water Health. 18 (2) 91-105. https://doi.org/10.2166/ wh. 2020.270

O'DONNELL K (1993) Fusarium and its near relatives. In: Reynolds DR and Taylor JW (eds) The Fungal Holomorph: Mitotic, Meiotic and Pleomorphic Speciation in Fungal Systematics. CAB International, Wallingford, Conn. 225-233.

PFALLER MA, DIEKEMA DJ and SHEEHAN DJ (2006) Interpretive breakpoints for fluconazole and Candida revisited: a blueprint for the future of antifungal susceptibility testing. Clin. Microbiol. Rev. 19 435-447. https://doi.org/10.1128/CMR.19.2.435-447.2006

PRILLINGER H, MOLNAR O, LECHNER $\mathrm{F}$ and LOPANDIC $\mathrm{K}$ (1999) Phenotypic and genotypic identification of yeasts from cheese. Antonie van Leeuwenhoek. 75 (4) 267-283. https://doi.org/ 10.1023/A:1001889917533 
RAGONNET-CRONIN M, HODCROFT E, HUE S, FEARNHILL E, DELPECH V, BROWN AJ and LYCETT S (2013) Automated analysis of phylogenetic clusters. BMC Bioinf. 14-31. https://doi. org/10.1186/1471-2105-14-317

RAJWA- KULIGIEWICZ A, BIALIK FJ and ROWINSKI PM (2015) Dissolved oxygen and water temperature dynamics in lowland rivers over various timescales. J. Hydrol. Hydromech. 63 (4) 353-363. https://doi.org/10.1515/johh-2015-0041

RAVIKUMAR S, WIN MS and CHAI LY (2015) Optimizing outcomes in immunocompromised hosts: understanding the role of immunotherapy in invasive fungal diseases. Front. Microbiol. 6 1322. https:// doi.org/10.3389/fmicb.2015.01322

SCHNEIDER J and LE CAMPION-ALSUMARD T (1999) Construction and destruction of carbonates by marine and freshwater cyanobacteria. Eur. J. Phycol. 34 417-426. https://doi.org/10.1080/096702699 10001736472

SHIELS MS, ALTHOFF KN, PFEIFFER RM, ACHENBACH CJ, ABRAHAM AG, CASTILHO J, CESCON A, D'SOUZA G, DUBROW R and ERON JJ and co-authors (2017) HIV infection, immunosuppression, and age at diagnosis of non-AIDS-defining cancers. Clin. Infect. Dis. 64 (4) 468-475.

SUSILOWATI S, SUTRISNO J, MASYKURI M and MARIDI M (2018) Dynamics and factors that affects DO-BOD concentrations of Madiun River. AIP Conference Proceedings. 2049 020052. https:// doi.org/10.1063/1.5082457

TRAORE A, MULAUDZI K, CHARI G, FOORD S, MUDAU L, BARNARD T and POTGIETER N (2016) The impact of human activities on microbial quality of rivers in the Vhembe District, South Africa. Int. J. Environ. Res. Public Health. 13 817. https://doi. org/10.3390/ijerph13080817

TOMOVA AA, KUJUMDZIEVA AV and PETROVA VY (2019) Carbon source influences Saccharomyces cerevisiae yeast cell survival strategies: quiescence or sporulation, Biotechnol. Biotechnological Equipment. 33 (1) 1464-1470. https://doi.org/10.1080/13102818.201 9.1674188

TRAN NH, REINHARD M and GIN KYH (2018) Occurrence and fate of emerging contaminants in municipal wastewater treatment plants from different geographical regions-a review. Water Res. 133 182-207. https://doi.org/10.1016/j.watres.2017.12.029
UNAIDS (Joint United Nations Programme on HIV and AIDS) (2018) UNAIDS Programme Coordinating Board sees South Africa's AIDS response first-hand. https://www.unaids.org/en/resources/pr esscentre/featurestories/2018/november/pcb-field-visit-south-africa (Accessed 24 February 2020).

UNDP (United Nations Development Programme) (2015) Sustainable Development Goals (SDGs). URL: https://www.undp.org/content/ undp/en/home/sustainable-development-goals.html(Accessed6May 2020).

VAN DER WALT IJ, WINDE F and NELL B (2002) Integrated catchment management: The Mooi River (North West Province, South Africa) as a case study. Geogr. Res. Lett. 28 109-126.

VAN WYK DAB, BEZUIDENHOUT CC and RHODE OHJ (2012) Diversity and characteristics of yeasts from water resources in the North West Province, South Africa. Water Sci. Technol. Water Supply. 12.4 422-430. https://doi.org/10.2166/ws.2012.009

VENTER A, BARNARD S, DICKINSON MA, JANSE VAN VUUREn S, LEVANETS A and TAYLOR JC (2013) Planktonic algae and cyanoprokaryotes as indicators of ecosystem quality in the Mooi River system in the North-West Province, South Africa. Water SA. 39 (5) 707-719. https://doi.org/10.4314/wsa.v39i5.16

WICKERHAM LJ (1951) Taxonomy of yeasts. United States Department of Agriculture Bull. No: 1029. US Department of Agriculture, Washington, D.C.

WINDE F (2010) Uranium pollution of the Wonderfonteinspruit, 1997-2008 Part 2: Uranium in water - concentrations, loads and associated risks. Water SA. 236 (3) 257-278.

WHO (World Health Organisation) (2016) UN Interagency Coordination Group (IACG) on Antimicrobial Resistance. https://www.who. int/antimicrobial-resistance/interagency-coordination-group/en/ (Accessed 6 May 2020).

ZUPANCIC J, NOVAK BABIC M, ZALAR P and GUNDE-CIMERMAN N (2016) The black yeast Exophiala dermatitidis and other selected opportunistic human fungal pathogens spread from dishwashers to kitchens. PLoS ONE. 11 (2) e0148166. https://doi.org/10.1371/journal. pone. 0148166 